\title{
Effect of Land Application of Phosphorus-Saturated Gypsum on Soil Phosphorus in a Laboratory Incubation
}

\author{
Karen L. Grubb, ${ }^{1}$ Joshua M. McGrath, ${ }^{2}$ Chad J. Penn, ${ }^{3}$ and Ray B. Bryant ${ }^{4}$ \\ ${ }^{1}$ USDA, National Institute of Food and Agriculture, Waterfront Centre, Washington, DC 20024, USA \\ ${ }^{2}$ Department of Environmental Science and Technology, University of Maryland, College Park, MD 20742, USA \\ ${ }^{3}$ Department of Plant and Soil Sciences, Oklahoma State University, Stillwater, OK 74078, USA \\ ${ }^{4}$ USDA, Agricultural Research Service, Bldg. 3702, Curtin Road, University Park, PA 16802, USA \\ Correspondence should be addressed to Joshua M. McGrath, mcgrathj@umd.edu
}

Received 6 July 2011; Revised 11 October 2011; Accepted 29 October 2011

Academic Editor: Artemi Cerda

Copyright ( $) 2012$ Karen L. Grubb et al. This is an open access article distributed under the Creative Commons Attribution License, which permits unrestricted use, distribution, and reproduction in any medium, provided the original work is properly cited.

Agricultural drainage ditches can deliver high loads of phosphorus $(\mathrm{P})$ to surface water. Installation of filter structures containing $\mathrm{P}$ sorbing materials (PSMs), including gypsum, is an emerging practice that has shown promise to reduce these $\mathrm{P}$ loads. The objective of this study was to evaluate what effect soil amendment with gypsum would have on soil $\mathrm{P}$ concentrations and forms in a laboratory incubation experiment. Gypsum was saturated at two levels with $\mathrm{P}$, and applied to a silt loam and a sandy loam at two rates. The treated soils were incubated in the laboratory at $25^{\circ} \mathrm{C}$, and samples were collected on eight dates between 0 and 183 days after amendment. Spent gypsum application did not significantly increase soil water-extractable or Mehlich 3 P when applied at typical agronomic rates. This appears to be a viable strategy to remove $\mathrm{P}$ from agricultural drainage waters but does not appear to provide any additional $\mathrm{P}$ fertilizer value.

\section{Introduction}

Accelerated eutrophication of the Chesapeake Bay has been identified as a priority natural resource concern [1]. According to the Chesapeake Bay Program Watershed Model Phase 4.3 agricultural sources account for $45 \%$ of the total phosphorus (P) delivered to the Chesapeake Bay [2]. The Delmarva Peninsula is comprised of the nine counties of the eastern shore of Maryland, Accomack and Northampton counties in Virginia, and the state of Delaware. The Delmarva Peninsula is home to a large concentration of poultry production, leading to a regional surplus of phosphorus (P). In the past, poultry manure was land applied based on crop nitrogen $(\mathrm{N})$ requirements. However, because the $\mathrm{P}: \mathrm{N}$ ratio found in manure is much higher than the $\mathrm{P}: \mathrm{N}$ ratio required by plants, excessive $\mathrm{P}$ application has occurred resulting in elevated soil $\mathrm{P}$ concentrations [3]. The lower portion of the Delmarva Peninsula is dominated by coarse textured soils, shallow groundwater tables, and agricultural drainage ditches. Phosphorus leaching to groundwater is greatly increased in sandy soils with limited capacity to retain
$\mathrm{P}$, in soils with high $\mathrm{P}$ saturation, and in ditch drained soils containing preferential flow pathways [4]. This combination of hydrology and agricultural practices has led to P loading to surface water through shallow subsurface pathways and environmental quality issues [5].

One possible way to reduce phosphorus loss is to use byproduct materials that can sorb phosphorus [6]. Phosphorus sorption is the process of adsorption and precipitation of $\mathrm{P}$ from dissolved to solid forms [7]. Phosphorus sorbing materials (PSMs) can provide a substrate for chemical fixation to occur through precipitation with metals or adsorption onto metal oxides or hydroxides. Phosphorus sorbing materials can be applied directly to soil or manure, broadcast into ditches, or used in flow-through structures [8]. Currently, flow-through filter structures, which utilize byproduct fluegas desulfurization gypsum (FGDG; $\mathrm{CaSO}_{4} \cdot 2 \mathrm{H}_{2} \mathrm{O}$ ), are being evaluated in agricultural drainage ditches on the lower Delmarva Peninsula [7-9].

The benefits of PSMs to remove or reduce phosphorus entering downstream waterways are well documented $[6,9-12]$. Land application of gypsum also has the potential 
to improve soil physical properties by alleviating surface crusting and compaction, increasing water infiltration and holding capacity, improving aggregate stability, and reducing water runoff and erosion when land applied [13]. In highly weathered soils and acid soils typical of the Delmarva Peninsula, USA gypsum improves subsoil physical properties by increasing water-stable aggregates and improving rooting conditions $[14,15]$. However, little is known about the availability of P from land-applied FGDG taken from spent insitu ditch filter structures. Therefore, a laboratory incubation study was conducted to imitate possible field conditions that would occur through the application of spent FGDG from a ditch filter. The objective of this study was to determine under laboratory conditions the effect of applying FGDG with added $\mathrm{P}$ to coastal plain soils on soil $\mathrm{P}$ concentrations and solubility over time.

\section{Materials and Methods}

2.1. Soil Incubation Study. A soil incubation study was initiated to determine and compare the effect of adding phosphorus-saturated FGDG on soil chemical properties. Treatments consisted of two soil types (silt loam and sandy loam), two gypsum rates (high rate and low rate), two gypsum $\mathrm{P}$ saturation rates (determined at $25 \%$ and $75 \%$ of the FGDG sorption maximum; see below for details), and seven sample dates. The treatments were assigned in a two (soil type) by two (FGDG rate) by two ( $\mathrm{P}$ rate) by seven (sampling date) factorial design, resulting in 56 treatment combinations. Each treatment combination was randomly assigned within four incubators, with each incubator serving as one block. The incubators used were VWR Scientific Model 2020 Low Temperature incubators set at $25^{\circ} \mathrm{C}$.

Sandy loam and silt loam soil samples were collected from the top 12 inches of soil from Maryland's eastern shore. The sites had a history of manure application but were chosen due to relatively low background P concentrations. The sandy loam was a Galestown siliceous, mesic Psammentic Hapludult, and was collected from the edge of a cultivated field located in Quantico, MD, USA, that was planted in corn when collected. The silt loam was a Mattapex finesilty, mixed, active, mesic Aquic Hapludult and was collected from the edge of a cultivated field located in Chestertown, MD, USA, planted in soybeans when collected. Soil classification was determined based on the USDA-NRCS Soil Survey information compiled on the Web Soil Survey (available online at http://websoilsurvey.nrcs.usda.gov/app /HomePage.htm, verified October 5 2011).

The soils were air-dried at approximately $20^{\circ} \mathrm{C}$, ground to pass through a $20-\mathrm{mm}$ wire screen, and then $200 \mathrm{~g}$ (dry weight) of soil was added to plastic cups. Each cup had a snap cap with four $3.97 \mathrm{~mm}$ holes drilled in the lid to allow for air exchange. Prior to amendment, a preincubation was conducted where each cup was brought to a moisture content equivalent to $70 \%$ of field capacity [16] and incubated at $25^{\circ} \mathrm{C}$ for 14 days. In addition to the treatment combinations described above, there was one cup in each block for each soil (eight total cups) placed in the preincubation. These samples
TABLe 1: Baseline water extractable phosphorus (WEP), Mehlich-3 phosphorus (M3P), organic matter (OM), and $\mathrm{pH}$ for each soil after 14-day preincubation at $25^{\circ} \mathrm{C}$, but prior to amendment.

\begin{tabular}{|c|c|c|c|c|}
\hline Soil type & Soil texture & $\begin{array}{r}\text { WEP } \\
(\mathrm{mg}\end{array}$ & $\begin{array}{l}\text { M3P } \\
\left.\mathrm{kg}^{-1}\right)\end{array}$ & $\begin{array}{l}\mathrm{OM} \mathrm{pH} \\
(\%)\end{array}$ \\
\hline $\begin{array}{l}\text { Galestown siliceous, mesic } \\
\text { Psammentic Hapludult }\end{array}$ & Sandy loam & 6.00 & 54.45 & $0.7 \quad 4.56$ \\
\hline $\begin{array}{l}\text { Mattapex fine silty, mixed, } \\
\text { active, mesic Aquic } \\
\text { Hapludult }\end{array}$ & Silt loam & 4.70 & 38.01 & $2.2 \quad 6.17$ \\
\hline
\end{tabular}

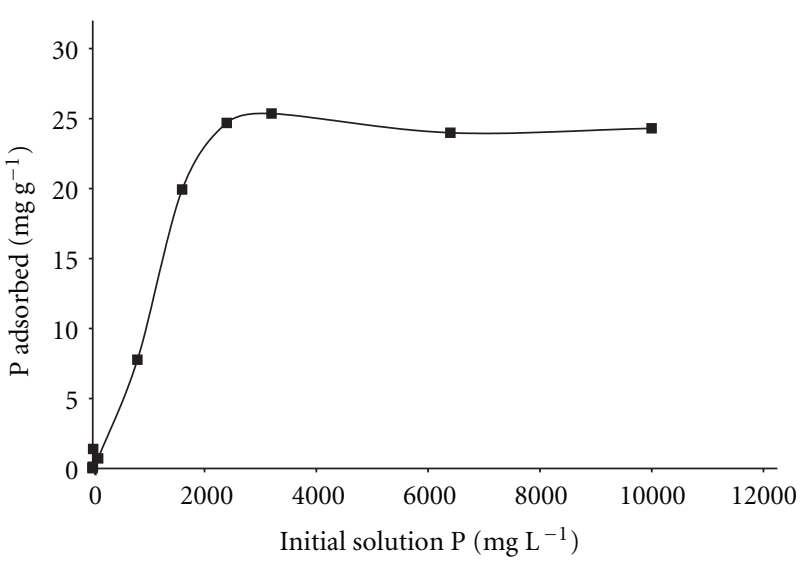

FIGURe 1: Cumulative phosphorus $(\mathrm{P})$ sorption curve generated by summing four sequential isotherms.

were analyzed at day 0 , prior to amendment, to determine $\mathrm{pH}$, organic matter (OM), Mehlich $3 \mathrm{P}(\mathrm{M} 3 \mathrm{P})$, and water extractable P (WEP) to establish baseline conditions (Table 1). Methods of analysis are presented below.

In order to determine the amount of $\mathrm{P}$ to add to the gypsum for the incubation study, $\mathrm{P}$ sorption isotherms were conducted. Gypsum was air-dried and sieved $(2 \mathrm{~mm})$ and $2 \mathrm{~g}$ of sample was weighed into $50 \mathrm{~mL}$ centrifuge tubes. Phosphorus solutions were made at 12 concentrations $(0,1$, 5, 10, 50, 100, 800, 1600, 2400, 3200, 6400, $10000 \mathrm{mg} \mathrm{P} \mathrm{L}^{-1}$ ) using $\mathrm{KH}_{2} \mathrm{PO}_{4}$ and deionized water. Four tubes with FGDG were amended with $30 \mathrm{~mL}$ of solution at each concentration for a total of 48 tubes. The $\mathrm{P}$ solution and soil were reacted in an end-over-end shaker for 24 hours. They were then centrifuged at $1163 \times \mathrm{G}$ and filtered through $0.45 \mu \mathrm{m}$ filters. The supernatant was analyzed for total dissolved $\mathrm{P}$ using inductively coupled plasma-optical emission spectroscopy (ICP-OES). This process was repeated three more times. A sorption curve was created by plotting the sum of $\mathrm{P}$ adsorbed during the four sequential sorption experiments versus the initial $\mathrm{P}$ concentration in solution (Figure 1). The point at which the cumulative curve (Figure 1) leveled off was assumed to represent the potential sorption maximum. At the sorption maximum, approximately $24.7 \mathrm{mg} \mathrm{g}^{-1}$ of $\mathrm{P}$ was sorbed with an initial $\mathrm{P}$ concentration of $2400 \mathrm{mg} \mathrm{L}^{-1}$. The amount of $\mathrm{P}$ adsorbed at 25 and $75 \%$ of this maximum was 
TABLE 2: Treatments resulting from combination of phosphorus saturation level (expressed as a percent of the isotherm maximum) and gypsum application rate and the resulting application rates of phosphorus $(\mathrm{P})$ and calcium $(\mathrm{Ca})$, and their effect on soil water extractable $\mathrm{P}$ (WEP) and Mehlich $3 \mathrm{P}$ (M3P) concentrations, averaged across time and soil type.

\begin{tabular}{|c|c|c|c|c|c|c|c|}
\hline \multirow{2}{*}{$\begin{array}{l}\text { Treatment } \\
\text { combination }^{\dagger}\end{array}$} & \multirow{2}{*}{$\begin{array}{c}\text { Phosphorus } \\
\text { saturation Level } \\
\% \text { of maximum }\end{array}$} & \multirow{2}{*}{$\begin{array}{c}\text { Gypsum } \\
\text { application Rate } \\
\left(\mathrm{Mg} \mathrm{ha}^{-1}\right)\end{array}$} & $\begin{array}{l}\text { P application } \\
\text { rate }\end{array}$ & $\begin{array}{l}\text { Ca application } \\
\text { rate }\end{array}$ & \multirow{2}{*}{$\begin{array}{c}\text { Gypsum } \\
\text { application rate } \\
\left(\mathrm{Mgha}^{-1}\right)\end{array}$} & $\mathrm{WEP}^{\ddagger}$ & $\mathrm{M} 3 \mathrm{P}^{\ddagger}$ \\
\hline & & & & $\left.a^{-1}\right)$ & & \multicolumn{2}{|c|}{$\left(\mathrm{mg} \mathrm{kg}^{-1}\right)$} \\
\hline LP-LG & $25 \%$ & 5.6 & 35 & 1232 & 5.6 & $4.5 \mathrm{~b}$ & $61.9 c$ \\
\hline HP-LG & $75 \%$ & 22.4 & 105 & 1232 & 22.4 & $7.1 \mathrm{~b}$ & $70.4 \mathrm{~b}$ \\
\hline LP-HG & $25 \%$ & 5.6 & 140 & 4928 & 5.6 & $6.6 \mathrm{~b}$ & $76.2 \mathrm{~b}$ \\
\hline HP-HG & $75 \%$ & 22.4 & 420 & 4928 & 22.4 & $20.8 \mathrm{a}$ & $117.3 \mathrm{a}$ \\
\hline
\end{tabular}

${ }^{\dagger}$ LP - LG, low phosphorus—high gypsum; HP-LG, high phosphorus—low gypsum; LP-HG, low phosphorus—high gypsum; HP-HG, high phosphorus— high gypsum.

${ }^{\ddagger}$ Means followed by different letters were determined to be significantly different at $P<0.05$.

approximated at 6.25 and $18.75 \mathrm{mg} \mathrm{g}^{-1}$, requiring initial $\mathrm{P}$ concentrations of 550 and $1550 \mathrm{mg} \mathrm{L}^{-1}$.

The FGDG was collected from US Gypsum Company in Baltimore, MD, and split into 8 batches into 5 gallon buckets. Using the data from the sorption isotherm, the material was saturated with $\mathrm{P}$ to reach the desired 25 and $75 \%$ levels. Phosphorus solutions at initial P concentrations of 550 and $1550 \mathrm{mg} \mathrm{L}^{-1}$ were prepared using deionized water and $\mathrm{KH}_{2} \mathrm{PO}_{4}$. In order to saturate the gypsum with $\mathrm{P}, 200 \mathrm{~g}$ of gypsum and $3.0 \mathrm{~L}$ of $550 \mathrm{mg} \mathrm{P} \mathrm{L}^{-1}$ solutionwere mixed in a Nalgene carboy and placed on the reciprocating shaker and allowed to react for 24 hours. An additional $200 \mathrm{~g}$ of gypsum and 3.0 $\mathrm{L}$ of $1550 \mathrm{mg} \mathrm{P} \mathrm{L}^{-1}$ solutionwere mixed in a Nalgene carboy and mixed for the same amount of time. After the reactions were complete, the excess solution was poured off and the gypsum was allowed to air dry.

After completion of the pre-incubation, soils were amended with the high and low $\mathrm{P}$ gypsum sources at two rates, 5.6 and $22.4 \mathrm{Mg} \mathrm{ha}^{-1}$, assuming $2244 \mathrm{Mg} \mathrm{ha}^{-1}$ of soil. The two levels of $P$ saturation and two rates of FGDG resulted in four treatment combinations: low $\mathrm{P}$ and low gypsum (LP-LG), high $\mathrm{P}$ and low gypsum (HP-LG), low $\mathrm{P}$ and high gypsum (LP-HG), and high $\mathrm{P}$ and high gypsum (HP$\mathrm{HG}$ ). The resulting $\mathrm{P}$ and $\mathrm{Ca}$ application rates associated with each treatment combination are presented in Table 2. After amendment, the cups were returned to the incubators $\left(25^{\circ} \mathrm{C}\right)$. During the incubation study, samples were weighed every 7 days, and sufficient deionized water was added to maintain the moisture content at $70 \%$ of field capacity. Cups were destructively sampled $1,7,28,63,91,119$, and 183 days after amendment. When removed, samples were oven-dried at $60^{\circ} \mathrm{C}$ for 24 hours and sieved using a $2-\mathrm{mm}$ sieve prior to sample analysis. All samples were then analyzed for WEP and M3P. Methods for each analysis are presented in more detail below.

2.2. Laboratory Analyses. Water-extractable $\mathrm{P}$ was determined by weighing $2 \mathrm{~g}$ of dried and sieved soil into $50 \mathrm{~mL}$ centrifuge tubes and adding $20 \mathrm{~mL}$ of deionized water. The tubes were then placed on their side in a reciprocating shaker and shaken on low speed for one hour. The tubes were then centrifuged at $1163 \times \mathrm{G}$ for 15 minutes then immediately filtered through $0.45 \mu \mathrm{m}$ filters using the Millipore filtration apparatus. Phosphate-P was determined using the molybdate blue method on a Lachat QuikChem 8500 Flow Injection Analysis System (Hach Company, Loveland, CO) by the methods of Murphy and Riley [17]. Mehlich $3 \mathrm{P}$ was determined by shaking $2.5 \mathrm{~g}$ of soil with $25 \mathrm{~mL}$ of Mehlich 3 solution $\left(0.2 \mathrm{M} \mathrm{CH}_{3} \mathrm{COOH}, 0.25 \mathrm{M} \mathrm{NH} \mathrm{NH}_{4}, 0.015 \mathrm{M}\right.$ $\mathrm{HNO}_{3}$, and $0.001 \mathrm{M} \mathrm{EDTA}$ ) in a $50 \mathrm{~mL}$ centrifuge tube for five minutes on a reciprocating shaker [18]. To determine $\mathrm{pH}, 10 \mathrm{~g}$ of dried and sieved soil was weighed into sample cups with $10 \mathrm{~mL}$ of deionized water to achieve a $1: 1$ volume: volume ratio. The mixture was stirred with a glass rod to achieve homogeneous slurry and then allowed to sit for 15 minutes and then stirred again. They sat another 15 minutes and were measured for $\mathrm{pH}$ using a Mettler Toledo InLab Expert Pro pH and Mettler Toledo InLab 731 EC probe and meter. Soil organic matter (OM) in the baseline samples was determined by loss-on-ignition [19].

2.3. Statistical Analysis. Statistics were conducted using SAS version 9.1. Although the experimental design was a randomized incomplete block design, the results were analyzed as a randomized complete block design (background samples were not considered in statistical analysis but were indicated as comparisons) in order to avoid using contrast statements. Incubators served as blocks, and the blocks were treated as a random factor. Due to large differences in background soil types (differences between sandy loam and silt loam), for some analyses data was sorted by soil type and soils were considered separately. Proc mixed was used as the data analysis, model. Tukey's multiple mean comparison test was used to make pair wise comparisons [20]. Significant differences in means was determined at $\alpha<0.05$.

\section{Results}

3.1. Effect of Gypsum Rate and Time on Soil pH. Soil $\mathrm{pH}$ was measured in the amended and unamended soils on days 1, 7, and 119 of the incubation. There was a significant interaction between gypsum rate and soil time and also time and soil type $(P<0.0001)$ for soil $\mathrm{pH}$, but $\mathrm{P}$ saturation level did not significantly influence soil $\mathrm{pH}$. The sandy loam exhibited significantly lower $\mathrm{pH}$ (4.30) than the silt loam (6.13) soil across all times and gypsum rates. When averaged across 
$\mathrm{P}$ saturation level and gypsum rate, the $\mathrm{pH}$ of the sandy loam decreased with time after amendment from 4.39 to 4.21, while the silt loam $\mathrm{pH}$ increased from 6.12 to 6.15 (Table 4). Like time after amendment, gypsum rate had a significant effect on soil $\mathrm{pH}$, but only for the sandy loam soils. When averaged across $\mathrm{P}$ saturation and time, the sandy loam soils amended at the higher rate of gypsum $\left(22.4 \mathrm{Mg} \mathrm{ha}^{-1}\right)$ had a significantly higher $\mathrm{pH}(4.44)$ than those amended at the lower rate (4.15). The $\mathrm{pH}$ of the silt loam soil at either gypsum rate was statistically higher than the $\mathrm{pH}$ of the sandy loam soil, but no statistical difference was found between the two rates in the silt loam (Table 4). Apparently, the finer texture and higher organic matter content of the silt loam buffered it better against changes in $\mathrm{pH}$ due to gypsum rate than the sandy loam soil.

3.2. Effect of Gypsum and Phosphorus Rate on Soil P Concentrations. Statistical analysis indicated that for soil WEP and M3P there was a significant interaction $(P<0.0001)$ between $P$ saturation level and gypsum rate. This would be expected as the combination of these two treatment factors results in four distinct $\mathrm{P}$ application rates (Table 2). Therefore, the means across $\mathrm{P}$ saturation level and gypsum rate are presented. However, since time and soil type did not interact with the $\mathrm{P}$ application rate (i.e., combination of gypsum rate and saturation level), the means across time and soil type are presented. Soil WEP ranged from 4.5 to $20.8 \mathrm{mg} \mathrm{kg}^{-1}$ over all dates and treatments. The LP-LG, HP-LG, and LPHG treatment combinations all produced statistically similar soil WEP concentrations with means over time and soil type of $4.5,7.1$, and $6.6 \mathrm{mg} \mathrm{kg}^{-1}$, respectively (Table 2). The HP-HG treatment resulted in a significantly higher WEP concentration $\left(20.8 \mathrm{mg} \mathrm{kg}^{-1}\right)$ than the other three treatment combinations. While not evaluated statistically, the background WEP concentration (no treatment added to soils) averaged across soil type was $6.5 \mathrm{mg} \mathrm{kg}^{-1}$ and appeared to be similar to the all but the HP-HG treatment.

Trends seen in the effect of $\mathrm{P}$ saturation level and gypsum rate on $\mathrm{M} 3-\mathrm{P}$ concentration were similar to changes in WEP concentrations. Soil M3-P ranged from $61.9 \mathrm{mg} \mathrm{kg}^{-1}$ to $117.3 \mathrm{mg} \mathrm{kg}^{-1}$ averaged over all dates and treatments. As seen with WEP, the HP-HG treatment combination resulted in significantly higher soil M3P concentrations ( $117.3 \mathrm{mg} \mathrm{kg}^{-1}$ ) than the other three treatments. The HP-LG and LP-HG treatment combinations produced statistically similar soil M3-P concentrations with means over time and soil type of $70.4 \mathrm{mg} \mathrm{kg}^{-1}$, and $76.2 \mathrm{mg} \mathrm{kg}^{-1}$ respectively. However, these treatments were statistically higher than the LP-LG treatment combination $\left(61.9 \mathrm{mg} \mathrm{kg}^{-1}\right)$. Although not evaluated statistically, the mean background soil M3P for (averaged across soil type) was $46.5 \mathrm{mg} \mathrm{kg}^{-1}$, which was lower than any of the soils amended with gypsum. In Maryland, soil test $\mathrm{P}$ is considered optimum (where no yield response would be expected to $\mathrm{P}$ fertilizer) from 44-93 mg $\mathrm{kg}^{-1}$ M3P $[21,22]$. Therefore, only the highest $\mathrm{P}$ application rate achieved with the HP-HG treatment resulted in soil test $\mathrm{P}$ concentrations that would be defined as "excessive" under Maryland's soil test interpretative categories.
Total $\mathrm{P}$ applied through the four treatment combinations had a dominant effect on soil WEP and M3-P. Total P rates added to the soil were $35,105,140$, and $420 \mathrm{~kg} \mathrm{ha}^{-1}$ with the LP-LG, HP-LG, LP-HG, and HP-HG treatments, respectively (Table 2 ). Substantially, more $\mathrm{P}$ was added with the HP-HG treatment, which was evidenced by significantly higher soil M-3P and WEP concentrations. The three lower $\mathrm{P}$ application rates resulted in statistically similar soil WEP concentrations. While no statistical comparisons could be made, these concentrations were similar to the background soil water-extractable $\mathrm{P}$ concentrations before amendment. These results indicate that addition of low $\mathrm{P}$, saturated gypsum and low rates of high $\mathrm{P}$, saturated gypsum did not add enough $P$ to substantially increase WEP. In fact, application of the low $\mathrm{P}$ saturation gypsum, at both the HG and LG gypsum rates, actually decreased soil water-extractable $\mathrm{P}$ relative to background conditions (Table 2 ). It is likely that the $\mathrm{Ca}$ added with $\mathrm{P}$, saturated gypsum was available in enough quantity to react with native soil $\mathrm{P}$ and sorb additional $\mathrm{P}$ from the soil solution. The molar ratio of the LPLG and LP-HG treatment combinations was 26.7: 1 (Ca:P) and only $8.9: 1$ for the HP-LG and HP-HG treatments.

The results of the water-extraction were mirrored by the M3-P results with the exception that M3-P concentrations were mostly a function of the amount of $\mathrm{P}$ added with each treatment combination. As seen in Table 2, the HPLG $\left(105 \mathrm{~kg} \mathrm{ha}^{-1}\right)$ and LP-HG $\left(140 \mathrm{~kg} \mathrm{ha}^{-1}\right)$ treatments added very similar amounts of $\mathrm{P}$, while the HP-HG $\left(420 \mathrm{~kg} \mathrm{ha}^{-1}\right)$ treatment added substantially more $\mathrm{P}$ and the LP-LG $\left(35 \mathrm{~kg} \mathrm{ha}^{-1}\right)$ added substantially less than the other three treatments. Similarly, there was a strong correlation between $\mathrm{P}$ added and M3-P concentrations $\left(R^{2}=0.99^{* * *}\right)$. Finally, the M3-P extraction showed an increase in soil $\mathrm{P}$ concentrations relative to the background soils upon $\mathrm{P}$ application among all treatment combinations. Therefore, one can conclude the M3 extraction apparently was more efficient at extracting the $\mathrm{P}$ held by the gypsum when compared to the water extraction where the three lower $\mathrm{P}$ rates did not show an increase in water-extractable $\mathrm{P}$ or a slight decrease compared to background levels. This is likely due to the fact that the M3 extract solution is acidic and efficient at dissolving Ca phosphates, the dominant $\mathrm{P}$ form found in $\mathrm{P}$ amended gypsum [11].

\subsection{Effect of Soil Type and Time on Soil P Concentrations.} Soil type and time had a significant interaction $(P<$ 0.0001 ), indicating that time did not affect WEP and M3P concentrations the same for each soil type. Therefore, the main effects of time and soil type on soil WEP and M3P are presented, averaged across all $\mathrm{P}$ saturation levels and gypsum application rates. Soil WEP concentrations in the sandy loam soils ranged from $17.8 \mathrm{mg} \mathrm{kg}^{-1}$ to $9.1 \mathrm{mg} \mathrm{kg}^{-1}$ and from $12.8 \mathrm{mg} \mathrm{kg}^{-1}$ to $4.6 \mathrm{mg} \mathrm{kg}^{-1}$ in the silt loam samples (Table 3 ). For both soil types, initial soil WEP concentrations (day 1) were significantly higher than the final soil WEP concentrations (day 183). Mehlich 3 P behaved slightly differently than WEP. Rather than decreasing steadily with time, it initially increased and then gradually decreased. 
TABLE 3: Effect of soil type and time on soil water-extractable phosphorus and Mehlich 3 phosphorus concentrations averaged across phosphorus saturation level and gypsum rate ${ }^{\dagger}$.

\begin{tabular}{|c|c|c|c|c|c|c|c|}
\hline \multirow[b]{2}{*}{ Soil type } & \multicolumn{7}{|c|}{ Days after Amendment } \\
\hline & \multicolumn{6}{|c|}{$\left(\mathrm{mg} \mathrm{kg}^{-1}\right)$} & 183 \\
\hline & \multicolumn{7}{|c|}{ Soil water extractable phosphorus concentration } \\
\hline Sandy loam & $17.8 \mathrm{a}$ & $14.3 \mathrm{ab}$ & $14.1 \mathrm{ab}$ & $15.0 \mathrm{ab}$ & $9.4 \mathrm{bc}$ & $9.5 \mathrm{bc}$ & $9.1 \mathrm{bc}$ \\
\hline Silt loam & $12.8 \mathrm{ab}$ & $8.0 \mathrm{bc}$ & $6.5 \mathrm{bc}$ & $5.6 \mathrm{bc}$ & $5.3 \mathrm{c}$ & $4.8 \mathrm{c}$ & $4.6 \mathrm{c}$ \\
\hline Unamended sandy loam & 6.8 & 6.8 & 5.9 & 5.2 & 5.3 & 5.3 & 5.3 \\
\hline \multirow[t]{2}{*}{ Unamended silt loam } & 5.2 & 5.3 & 5.7 & 4.8 & 4.1 & 4.1 & 4.0 \\
\hline & \multicolumn{7}{|c|}{ Soil Mehlich 3 phosphorus concentration } \\
\hline Sandy loam & $73.2 \mathrm{~d}$ & $57.6 \mathrm{~d}$ & $98.3 \mathrm{bc}$ & $111.8 \mathrm{ab}$ & $127.1 \mathrm{a}$ & $87.2 \mathrm{c}$ & $83.5 \mathrm{c}$ \\
\hline Silt loam & $64.2 \mathrm{~d}$ & $62.3 \mathrm{~d}$ & $68.9 \mathrm{~d}$ & $107.2 \mathrm{~b}$ & $91.1 \mathrm{c}$ & $58.5 \mathrm{~d}$ & $50.0 \mathrm{~d}$ \\
\hline Unamended sandy loam & 49.3 & 54.9 & 57.0 & 82.1 & 99.7 & 62.9 & 60.7 \\
\hline Unamended silt loam & 41.0 & 35.6 & 42.0 & 77.8 & 69.8 & 42.2 & 37.8 \\
\hline
\end{tabular}

${ }^{\dagger}$ Means followed by different letters were determined to be significantly different at $P<0.05$. Means for the unamended soils were not compared statistically to the amended soils.

TABle 4: Combined effect of soil type and time averaged across phosphorus (P) saturation level and gypsum rate and combined effect of soil type and gypsum rate averaged across time on soil $\mathrm{pH}^{\dagger}$.

\begin{tabular}{lccc}
\hline Soil type & \multicolumn{3}{c}{ Days after Amendment } \\
& 1 & 7 & 119 \\
\hline Sandy loam & $4.39 \mathrm{~d}$ & $4.28 \mathrm{e}$ & $4.21 \mathrm{f}$ \\
Silt loam & $6.12 \mathrm{~b}$ & $6.11 \mathrm{c}$ & $6.15 \mathrm{a}$ \\
\hline Unamended sandy & 4.55 & 4.44 & 4.18 \\
loam & & & \\
Unamended silt & 6.29 & 6.27 & 6.22 \\
loam & Gypsum Rate $\left(\mathrm{Mg} \mathrm{ha}^{-1}\right)$ & \\
& 5.6 & 22.4 & \\
& $4.15 \mathrm{c}$ & $4.44 \mathrm{~b}$ \\
Sandy Loam & $6.11 \mathrm{a}$ & $6.14 \mathrm{a}$ & \\
Silt Loam &
\end{tabular}

${ }^{\dagger}$ Means followed by different letters were determined to be significantly different at $P<0.05$. Means for the unamended soils were not compared statistically to the amended soils.

In the silt loam M3-P ranged from 50.0 (day 183) to $107.2 \mathrm{mg} \mathrm{kg}^{-1}$ (day 63) and in the sandy loam M3P ranged from 57.6 (day 7) to $127.1 \mathrm{mg} \mathrm{kg}^{-1}$ (day 91, Table 3).

The silt loam soil had a higher buffer capacity than the sandy loam. This can be seen in Table 3 where P application had a greater impact on the sandy loam than the silt loam, dramatically increasing WEP concentrations relative to the unamended soil. This can be attributed to the higher clay and silt content and therefore greater surface area for $\mathrm{P}$ retention found in the silt loam compared to the sandy loam. In addition, the higher $\mathrm{P}$ buffer capacity and lower $\mathrm{P}$ saturation of the silt loam allowed $\mathrm{P}$ concentrations to return to near background levels for both water-extractable $\mathrm{P}$ and M3-P compared to the sandy loam.

Comparison of the trends in WEP and M3P (Table 3) indicates that $\mathrm{P}$ was moving between different $\mathrm{P}$ pools during the incubation study. The WEP concentrations peaked almost immediately after $\mathrm{P}$ application, probably reflecting soluble inorganic $\mathrm{P}$ applied with the saturated gypsum. Conversely, the M3-P concentrations increased gradually with time, peaking between days 63 (silt loam) and 91 (sandy loam), and then gradually decreased to concentrations near those found in the unamended soil. Water-extractable P, which was probably dominated by inorganic $\mathrm{P}$, was quickly reduced either by sorption processes in the soil or microbial immobilization. Apparently the amount of $\mathrm{P}$ added with the gypsum was minor relative to the pool of M3P already present in the soils as concentrations were only increased slightly above background $\mathrm{P}$ concentrations. The peak in $\mathrm{M} 3 \mathrm{P}$ seen in the amended soils was also seen in the unamended soils indicating that the changes seen with time were more likely related to soil microbial activity rather than the gypsum and $\mathrm{P}$ applications. Fundamentally, this data shows that with time soils can fix (through chemical or microbial processes) most of the $\mathrm{P}$ added with saturated gypsum at the $\mathrm{P}$ application rates used in this study. However, the finer textured soils with higher $\mathrm{P}$ buffering capacity are better able to sorb this added $\mathrm{P}$.

\section{Discussion}

The purpose of this study was to determine what effect gypsum saturated with $\mathrm{P}$ would have on soil $\mathrm{P}$ forms and concentrations. This was designed as a preliminary, laboratory experiment to determine if spent gypsum, which had been removed from an agricultural ditch filter, could be land applied without increasing the risk of $\mathrm{P}$ losses in runoff from amended soils. In addition, it was hypothesized that such spent gypsum could be used as a P fertilizer source. However, there are many more variables that influence $P$ release under field conditions. Therefore, further field research should be conducted, based on this work, to evaluate potential plant availability and environmental impact of land application 
of spent gypsum from ditch filters. It is unlikely that the gypsum removed from agricultural drainage filters would have $\mathrm{P}$ concentrations as high as evaluated in this study. Therefore, the gypsum used in this study should present a greater risk or have greater potential as a fertilizer than what would be seen in the field. Kleinman et al. [23] evaluated ditches on Maryland's eastern shore and found ditch water $\mathrm{P}$ concentrations ranged from 0.51 to $6.17 \mathrm{mg} \mathrm{L}^{-1}$ total P. By comparison, $\mathrm{P}$ solution concentrations used to spike the gypsum in this study were 550 and $1550 \mathrm{mg} \mathrm{P} \mathrm{L}^{-1}$ for the low and high $\mathrm{P}$ saturation levels, respectively. Therefore, the materials used in this study were reacted with solutions containing substantially higher P concentrations. Even with the high P saturation levels used in this study, when applied at a realistic field application rates of $5.6 \mathrm{Mg} \mathrm{ha}^{-1}$, there were no significant differences in the amount of $\mathrm{P}$ extracted between the two P saturation levels. Therefore, applying "spent" gypsum at typical amendment rates would not appear to result in any detrimental water quality impacts. In fact, soil amendment with spiked gypsum resulted in little change of WEP or M3$\mathrm{P}$ concentrations at all but the highest total $\mathrm{P}$ application rate (HP-HG) relative to background soil P concentrations.

The current laboratory study showed that there may be some potential to increase soil M3-P concentrations through the land application of spent gypsum. However, timing of application to allow for the P to enter the labile pool would need to be accounted for. The $\mathrm{P}$ application rates used in this study were probably much higher than what would be seen in the field and only the highest rate was enough to move soil test $\mathrm{P}$ to a higher interpretative category per Maryland recommendations [21]. Further studies would be required, using actual spent gypsum with realistic P saturation levels, to determine the actual fertilizer value.

In conclusion, since the application of spent gypsum from a ditch filter did not appear to increase soil WEP or the interpretative ranking of soil test $\mathrm{P}(\mathrm{M} 3 \mathrm{P})$, it does not appear that land application of spent gypsum would increase relative environmental risk or provide any $\mathrm{P}$ fertilizer value, especially at $\mathrm{P}$ concentrations expected to be found in the real world. It appears that $\mathrm{P}$ captured by gypsum filters is effectively trapped in rather insoluble forms. Therefore, the removal of $\mathrm{P}$ from agricultural drainage using gypsum and its subsequent land application is in effect relocating soil $\mathrm{P}$ from a relatively mobile soil $\mathrm{P}$ pool, that was subsequently lost as dissolved $\mathrm{P}$ in runoff or subsurface flow, to a stable soil P pool where it is unlikely to be lost, even if it is applied back to the same field. In addition, the application of spent gypsum to high $\mathrm{P}$ soils may further reduce $\mathrm{P}$ losses by removing soluble $\mathrm{P}$ from the soil solution. Consideration of soil type and time of application is important in determining the environmental and agronomic impacts of applying the spent materials. The results of this study indicate that when applied as a soil amendment; spent gypsum would retain its $\mathrm{P}$, presenting little risk of loosing that $\mathrm{P}$ to surface runoff. However, it does not appear to be a viable fertilizer source except at the highest $\mathrm{P}$ saturation level and application rate, which would be unlikely in agronomic settings. Once again the authors stress that field evaluation should be conducted to confirm these laboratory findings.

\section{Abbreviations}

\author{
ICP-OES: Inductively coupled plasma—optical \\ emission spectroscopy \\ M3P: $\quad$ Mehlich 3 aluminum, iron, and \\ Phosphorus, respectively \\ WEP: Water-extractable phosphorus.
}

\section{Acknowledgments}

This project was funded in part by a USDA-NRCS Conservation Innovation Grant (Award number NRCS 69-3A75-7116). In addition, the authors wish to give special thanks to Dr. Bahram Momen for his guidance in statistical analysis of the data.

\section{References}

[1] B. Obama, Executive Order: Chesapeake Bay Protection and Restoration, 2009.

[2] CBPO, "Sources of phosphorus loads to the Bay," 2009, http:// www.chesapeakebay.net/status_phosphorusloads.aspx?menuitem $=19801$.

[3] D. H. Pote, T. C. Daniel, A. N. Sharpley, P. A. Moore, D. R. Edwards, and D. J. Nichols, "Relating extractable soil phosphorus to phosphorus losses in runoff," Soil Science Society of America Journal, vol. 60, no. 3, pp. 855-859, 1996.

[4] J. T. Sims, R. R. Simard, and B. C. Joern, "Phosphorus loss in agricultural drainage: historical perspective and current research," Journal of Environmental Quality, vol. 27, no. 2, pp. 277-293, 1998.

[5] P. A. Vadas, M. S. Srinivasan, P. J. A. Kleinman, J. P. Schmidt, and A. L. Allen, "Hydrology and groundwater nutrient concentrations in a ditch-drained agroecosystem," Journal of Soil and Water Conservation, vol. 62, no. 4, pp. 178-188, 2007.

[6] J. W. Leader, E. J. Dunne, and K. R. Reddy, "Phosphorus sorbing materials: sorption dynamics and physicochemical characteristics," Journal of Environmental Quality, vol. 37, no. 1, pp. 174-181, 2008.

[7] C. J. Penn, R. B. Bryant, P. J. A. Kleinman, and A. L. Allen, "Removing dissolved phosphorus from drainage ditch water with phosphorus sorbing materials," Journal of Soil and Water Conservation, vol. 62, no. 4, pp. 269-276, 2007.

[8] C. J. Penn, J. M. McGrath, and R. B. Bryant, "Ditch drainage management for water quality improvement," in Agricultural Drainage Ditches: Mitigation Wetlands for the 21st Century, M. T. Moore and R. Kroger, Eds., Research Signpost, Kerala, India, 2010.

[9] D. Stoner, C. Penn, and J. McGrath, "Phosphorus sorption onto by-products ina flow through setting: effect of material properties," Journal of Environment Quality. In press.

[10] C. J. Penn and J. M. McGrath, "Predicting phosphorus sorption onto steel slag using a flow-through approach with application to a pilot scale system," Journal of Water Resource and Protection, vol. 3, no. 4, pp. 235-244, 2011.

[11] C. J. Penn et al., "Use of industrial by-products to sorb and retain phosphorus," Communications in Soil Science and Plant Analysis, vol. 42, pp. 633-644, 2011.

[12] R. B. Brennan, O. Fenton, M. Rodgers, and M. G. Healy, "Evaluation of chemical amendments to control phosphorus losses from dairy slurry," Soil Use and Management, vol. 27, no. 2, pp. 238-246, 2011. 
[13] R. B. Clark, K. D. Ritchey, and V. C. Baligar, "Benefits and constraints for use of FGD products on agricultural land," Fuel, vol. 80, no. 6, pp. 821-828, 2001.

[14] M. E. Sumner, D. E. Radcliffe, M. McCray, E. Carter, and R. L. Clark, "Gypsum as an ameliorant for subsoil hardpans," Soil Technology, vol. 3, no. 3, pp. 253-258, 1990.

[15] K. D. Ritchey, R. F. Korcak, C. M. Feldhake, V. C. Baligar, and R. B. Clark, "Calcium sulfate or coal combustion by-product spread on the soil surface to reduce evaporation, mitigate subsoil acidity and improve plant growth," Plant and Soil, vol. 182, no. 2, pp. 209-219, 1996.

[16] K. H. Tan, Soil Sampling, Preparation, and Analysis, Taylor \& Francis, 2005.

[17] J. Murphy and J. P. Riley, "A modified single solution method for the determination of phosphate in natural waters," Analytica Chimica Acta, vol. 27, pp. 31-36, 1962.

[18] A. Mehlich, "Mehlich 3 soil test extractant: a modification of Mehlich 2 extractant," Communications in Soil Science \& Plant Analysis, vol. 15, no. 12, pp. 1409-1416, 1984.

[19] D. A. Storer, "A simple high sample volume ashing procedure for determination of soil organic matter," Communications in Soil Science \& Plant Analysis, vol. 15, no. 7, pp. 759-772, 1984.

[20] J. W. Tukey, The Problem of Multiple Comparisons, Princeton University, 1953.

[21] F. J. Coale, "Descriptions of the soil test interpretive categories used by the University of Maryland soil testing laboratory," in SFM-3, U. O. M. Extension, Ed., University of Maryland Extension, College Park, Md, USA, 1996.

[22] J. M. McGrath and F. J. Coale, "Converting among soil test analyses frequently used in Maryland," in SFM-4, U. O. M. Extension, Ed., University of Maryland Extension, College Park, Md, USA, 2006.

[23] P. J. A. Kleinman, A. L. Allen, B. A. Needelman et al., "Dynamics of phosphorus transfers from heavily manured Coastal Plain soils to drainage ditches," Journal of Soil and Water Conservation, vol. 62, no. 4, pp. 225-235, 2007. 

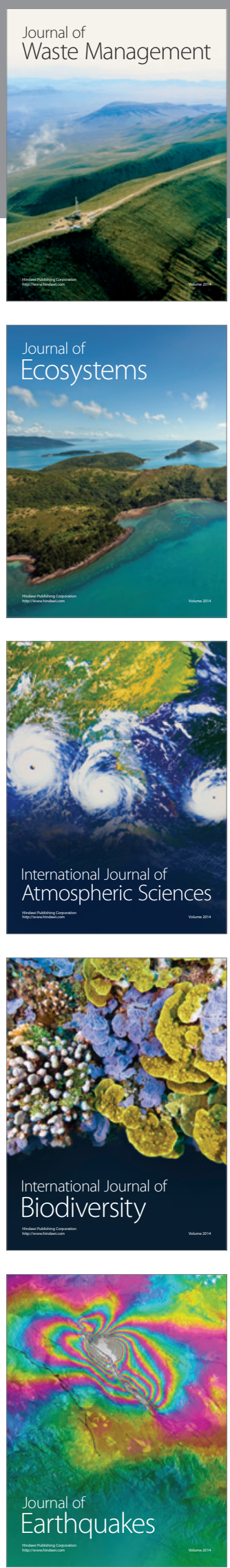
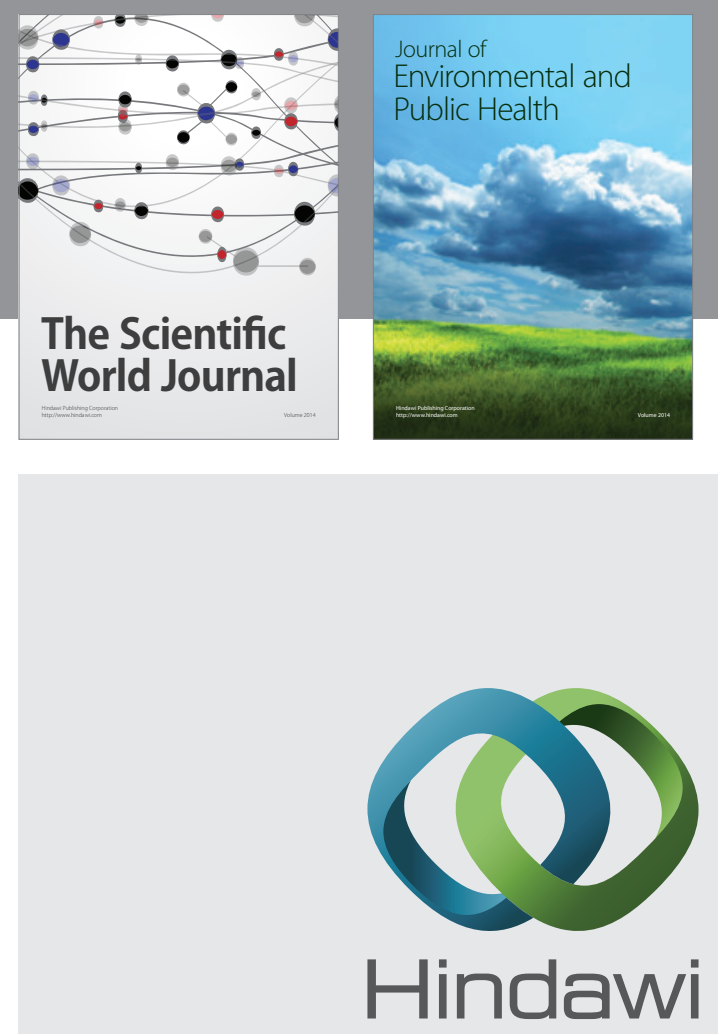

Submit your manuscripts at

http://www.hindawi.com
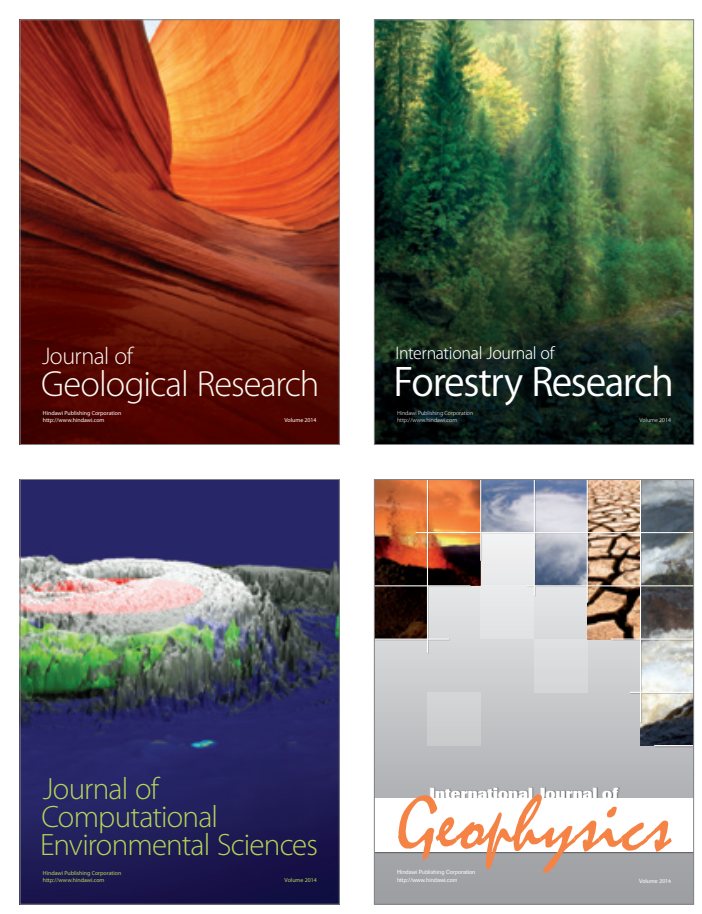
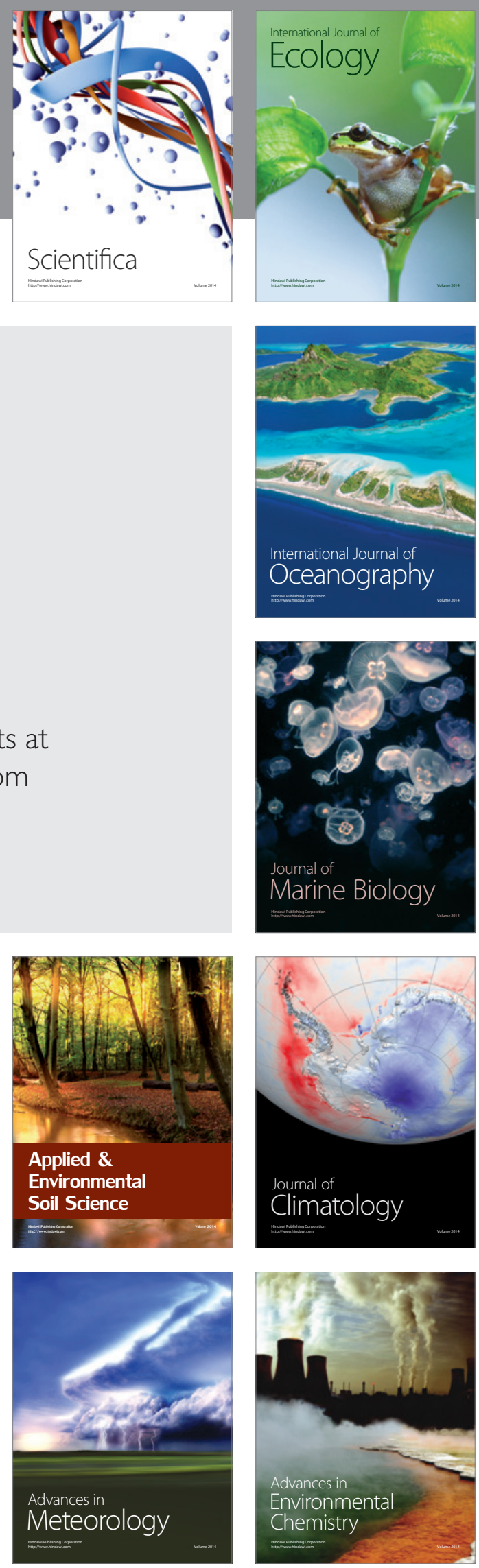